DOI: https://doi.org/10.34069/AI/2021.47.11.13

How to Cite:

Akkurt, V., Korolova, T., \& Popova, O. (2021). Persuasion prosody in prosecutor's speech: Ukrainian and english. Amazonia Investiga, 10(47), 125-141. https://doi.org/10.34069/AI/2021.47.11.13

\title{
Persuasion prosody in prosecutor's speech: Ukrainian and english
}

\section{Просодія переконання в промові прокурора: українська та англійська мови}

Received: September 30, 2021

Accepted: November 6, 2021

\author{
Written by: \\ Akkurt Vladyslava: \\ https://orcid.org/0000-0003-3542-3428 \\ Korolova Tetiana ${ }^{56}$ \\ https://orcid.org/0000-0003-3441-196X \\ Popova Oleksandra ${ }^{57}$ \\ https://orcid.org/0000-0002-6244-5473
}

\begin{abstract}
This paper presents the research of prosodic means conveying the persuasion modality in a prosecutor's speech in court. The material under study consists of English and Ukrainian speeches of the prosecutors (the total duration time is 16 hours). The results of the experimental material examination demonstrate common and specific characteristics of prosody components (melody, loudness, tempo, timber and sentence stress) in English and Ukrainian. Pragmatics of prosody semantics and correlation between its parameters have been proved. It has been stated that in both English and Ukrainian an utterance becomes emphatic due to the prosodic means of persuasion in a prosecutor's speech as follows: 1) changes of tempo;2) changes of the pitch of a voice; 3 ) replacements of the rising tone with the falling one and vice versa; 4) usage of complex tones; 5) use of an interrupted ascending or descending scale; 6) change of sentence stress type; 7) division of a sense group into two or more parts. The above mentioned facts enable us to conclude that: while describing the first of these aspects of typological similarity of prosody in the compared languages, the parameters of the pitch component of intonation are most informative when differentiating attitudinal ones. The specificity of interaction between prosodic and grammar means when expressing persuasion in Ukrainian and English prosecutor's speech is caused by a degree of distinction between the
\end{abstract}

\begin{abstract}
Анотація
У цій роботі представлено дослідження просодичних засобів, що передають модальність переконання у виступі прокурора в суді. Досліджений матеріал складається 3 виступів прокурорів англійською та українською мовами (загальна тривалість 16 годин). Результати дослідження експериментального матеріалу демонструють спільні та специфічні характеристики компонентів просодії (мелодія, гучність, темп, тембр і фразовий наголос) в англійській та українській мовах. Доведено прагматику семантики просодії та кореляцію між іiі параметрами. Встановлено, що як в англійській, так і в українській мові висловлювання стає емфатичним завдяки просодичним засобам переконання у промові прокурора: 1) зміни темпу; 2) зміни висоти голосу; 3) заміни висхідного тону на низхідний i навпаки; 4) використання складних тонів; 5) використання перерваної висхідної чи низхідної шкали; 6) зміна типу фразового наголосу; 7) поділ смислової групи на дві або більше частин. Наведені вище факти дають змогу дійти висновку, що: описуючи перший із цих аспектів типологічної подібності просодії в порівнюваних мовах, параметри звукового компонента інтонації $\epsilon$ найбільш інформативними при диференціації ставлення. Специфіка взаємодії просодичних i граматичних засобів при вираженні
\end{abstract}

\footnotetext{
${ }^{55}$ Stakeholder, Chair of Translation, Theoretical and Applied Linguistics Place of employment: State institution "South Ukrainian National Pedagogical University named after K. D. Ushynsky" Scientific degree: CSc. (Philology), Ukraine.

${ }^{56}$ Chairperson, Chair of Translation, Theoretical and Applied Linguistics Place of employment: State institution "South Ukrainian National Pedagogical University named after K. D. Ushynsky", Ukraine.

${ }^{57}$ Dean of the Foreign Languages Department Place of employment: State institution "South Ukrainian National Pedagogical University named after K. D. Ushynsky", Ukraine.
} 
grammatical and vocabulary systems of the compared languages.

Keywords: persuasion modality, prosecutor's speech, court, speech expressiveness, prosody semantics.

\section{Introduction}

The speech of the public prosecutor is a consistent part of court procedure as a part of juridical discourse. Although there are many researches devoted to juridical discourse (Baum, 2006; Dubovsky \& Yermolenko, 1987; Gold, 1987, Klimovich, 2016; Schwartz, 1997; Tiersma, 1999), to the role of the prosecutor in the trial (Shevchenko, 1983; Shvetsova, 2012; Shulga, 2016) and the problems of modality in legal communication as well (Laufer, 1993; Palmer, 1974; Spence, 1996; Chemerinsky, 2003; Wang, 2004) there can hardly be found works examining the prosody of persuasion in the prosecutor's speech.

Thus, taking into account the prosecutor's responsibility in the trial discussion, importance of linguistic means used in his speech directed at convincing the audience in the unshakability of the facts presented in the discussion this research can be considered the one of importance for both the scientists and the practicing individuals as well.

The role of prosody among the other linguistic means in actualising the prosecutor's speech deserves a particular attention. There are many works dealing with prosody (Brovchenko \& Korolova, 2020; Bybee, 2003; Korolova, 1989; Palmer, 1974) and still the problem of attitudinal prosodic structure requires empirical data and theoretical systematisation.

\section{Theoretical Framework}

\section{Prosecutor's speech as an important component of the multifactorial juridical discourse}

Juridical discourse is regarded as a kind of legal discourse - the communicative activities aimed at regulating social relations through a stable system of legal norms. Juridical discourse is realized in communicative communities of the institutional type that perform legal functions (parliament, court, police, prosecutor's office, barrister's one and notary). Differentiation of types of legal discourse (legislative, переконання в українському та англійському прокурорському мовленні зумовлена певною відмінністю між граматичною та словниковою системами порівнюваних мов.

Ключові слова: модальність переконання, промова прокурора, суд, виразність мовлення, семантика просодії.

jurisdictional, discourse of general supervision and control, penitentiary, notarial, discourse of advocacy, etc.) is conditioned by the specific goals and functions of communication in the institutional system and manifests itself in typical texts, institutional symbols and behavioural stereotypes (Vargas, 1984). At the same time, legal discourse is not a collective phenomenon, but a holistic one and is not reduced to its varieties, in particular to judicial discourse; denotes a single, logically constructed system, parts of which absorb the characteristics of the whole. Judicial discourse is a clear example of institutional discourse with its typical characteristics. Clear division of roles, status inequality of participants, among which a hierarchy is built in the form of a pyramid with non-professional participants at its base and a judge as the holder of the highest status at the top. Judicial discourse is ritualized, and recurring situations of interaction are enshrined in specific genre forms. Different genres have various degrees of ritualization and leave more or less freedom in the choice of communicative behaviour and personal manifestations.

A distinctive feature of juridical discourse is the fact that communicative behaviour of the participants is conditioned by law. The most important points are reflected in the criminal procedure and civil procedure codes. In addition, codes of judicial ethics, even without legislative force or some recommending documents, determine the language behaviour of professional participants in the trial. Nevertheless, the Ukrainian scholars (Vorobey et al., 2021) highlight cases where traditional legislative procedures are characterised by increased emotionality.

In this research the following definition of the juridical discourse is taken into consideration: a verbal-symbolic representation of the communicative process during the trial, which is considered in the socio-historical, nationalcultural, defined situational context, the characteristics and intentions of communicators 


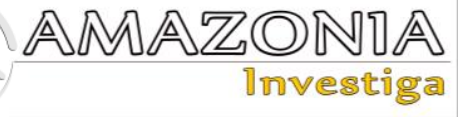

are taken into account (Dubrovskaya, 2010; Klimovich, 2016).

The specific factors that shape the communicative situation in court and speech of a prosecutor include the following.

1. The specificity of the grounds to join the communication: committed an act that contains signs of a crime. The subjects of communication are either direct participants in this act and eyewitnesses or some persons who are to reconstruct the model of the event.

2. Manifestation of the conflict communication elements (prosecutor $\longleftrightarrow$ lawyer). The phenomenon of "role opposition" is at the heart of this conflict; it is characterised by the fact that the conflict was anticipated due to the fact that one party (accusation) opposes the other (defence).

3. A high degree of formal communication, which is apriority characterised by all participants of the process by the goals and ways to achieve them through a definite division of roles. Formal communication involves a state of increased mental activity of persons endowed with the procedure powers that is naturally reflected in the language (Biber, 1988; Bickerton, 1996; Dowis, 1999).

4. Communication within the court is regulated by the rules of criminal procedure law and is subordinated to the court (Vinogradov, 1986, p. 10).

In some cases, we can correlate a speech of a prosecutor with the features of the publicistic style which comprises these subdivisions: journalistic articles; essays, including their shorter (on philosophical, social, aesthetic, or literary subjects) and longer (reviews, memoirs, treatises) forms; oratorical radio, and TV commentary. We should keep in mind that information in media is presented in various types of journalistic messages (Panasenko, 2016), i.e. in texts, which have a specific volume, structure, and content; they (journalistic messages) "contain categories, like coherence, cohesion, information value, anthropocentricity, modality, emotivity, etc." (Panasenko et al., 2018, p. 146). The designated peculiarities manifest themselves at the phonetic level.

Persuasion in a motivated juridical speech improves the quality of justice in cases heard by a jury, and demonstrates the authority of the prosecutor's office, as well as the personal prestige of the public prosecutor as a representative of a special kind of civil service. The speech of the public prosecutor is addressed not only to the court, but significantly affects the formation of legal awareness of the participants in the process, present in the courtroom. Therefore, the prosecutor has great responsibility when preparing his / her speech before the court. The public prosecutor's speech is one of the most important moments in the trial. Having participated in the discussion of the parties, the prosecutor is the first to summarize the court session in the auditorium, on behalf of the state he / she is the first to describe the actions of the defendant, to summarize the final opinion that he came to during the trial, and puts forward the conclusion of his / her activities as a public prosecutor.

\section{Persuasion as an obligatory element of the communicative behaviour in court}

An important component of modifying the interlocutors' behaviour is the psychological influence. Since the ancient times, public prosecutors have sought to influence judges by their speeches. One of important factors of the above-mentioned is based on the difference between the concepts "suggestion" and "persuasion" that are two types of linguistic influence. This dichotomy goes back to the Aristotle concept of rhetoric, according to which the rhetorician has two levers of influence on the audience - logical and emotional (Aristotle, 1978). If persuasion is carried out mainly through an appeal to knowledge and common sense, then the suggestion is based on emotions. To do this, the speaker appeals to the emotions of the object of influence, thereby seeking to bring it to the desired psychological state.

In our view, psychological influence, as a strategy aimed at the unconscious state of a human being, his / her emotions and feelings, appealing to the will of the recipient, opposes the strategy of persuasion, as a strategy of logical reasoning, and can employ multiple suggestive and manipulative tactics.

Persuasion - a term with two psychological interpretations (Laufer, 1993; Spence, 1996). This is the element of the worldview of the individual, which motivates him / her to act in a certain way, and the process of transferring an element of the addressee's worldview to another person. In scientific debates, the truth is also born due to the opponent's belief in the veracity of the proposed theory. As a rule, the speaker defends his / her own point of view putting forward the corresponding arguments, and the listener 
comprehends it and decides whether to agree with what is said or not. Thus, persuasion is a conscious process of perceiving information and accepting it as one's own belief; as a result, a person gets a new opinion of his own.

The language of the accuser during the court hearing is aimed at influencing the interlocutor in order to persuade. This is one of the main motives of the prosecutor's communication.

The prosecutor, expressing his position, in which he seeks to convince the interlocutor, can claim that his statement acquired the meaning of "truth" or "one of the points of view." Besides, the addressee may show some flexibility in presenting his position that is to have various degrees of confidence in his position.

Forms of persuasion tactics implementation in the prosecutor's speech are highly variable depending on the situation, the nature of the interlocutors, the importance of the purpose and so on. These communicative factors determine the choice of persuasion modality, the evaluative components that are present in the prosecutor's communicative behaviour and influence the interlocutor.

Modality is an integral component of the communicative tactics of persuasion in prosecutor's speech. The choice of modality affects the effectivity of achieving the goal set by the prosecutor - to influence the interlocutor and persuade him to accept the desired point of view. By its origin, semantic scope, variety and richness of linguistic means, modality is one of the fundamental language categories. The diversity of the means to present modal semantics influences the multifaceted nature of the proposed meaning. A review of scientific research on the problem of modality gives grounds to say that the classification of sentences on the modal basis, as well as the differentiation of the modal meanings themselves, shows a variety of views (Brovchenko \& Korolova, 2020).

However, there are currently at least two centres of consolidation within the modality semantic zone: the speaker's attitude to the situation (or "evaluation") and the status of the situation in relation to the real world (or "unreality») (Shvedov, 1980). It seems that all the variety of modal meanings (even in the broadest interpretations of modality) is somehow connected with one of these two concepts (or with both of them).
This is consistent within the interpretation of modality in the functional-semantic approach, which is based on the so-called broad looks at modality that combines the views of V. V. Vinogradov on understanding of modality (1975), the concept of subjective-objective syntactic categories (Peshkovsky, 1956) and the theory on interjections and modal words that convey the details of subjective modality in all kinds of linguistic presentation in the language of the prosecutor (Meshchaninov, 1946). Treating modality as a functional-semantic phenomenon also includes definition of the verb as a category that expresses the speaker's attitude to the content of the sentence (Jespersen, 1958), the concept of communicative-grammatical categories (Shvedov, 1980), views on the modality of other famous linguists.

The description of the persuasion modality in the prosecutor's speech is based on the following conceptual basis "the relation of the message contained in the sentence to reality" (Korolova, 1989) and the speaker's attitude to the uttered. Since the system of modal meanings of persuasion has no clear external and internal boundaries, it is advisable to apply the concept of "field".

Thus, convincing messages in the prosecutor's speech may differ in terms of objectivity / subjectivity, the degree of confidence in the statement. To persuade the interlocutor, the accuser may involve epistemic and optative modalities, that is to evaluate the facts presented by him as probable / improbable, desirable / undesirable.

Based on this definition, the functional scope of persuading modality is three-dimensional and can involve to modal semantic such meanings as reality / unreality, desirability, order; truth / falsity of information; affirmation / negativity, and many subjective-modal meanings: confidence / uncertainty, agreement, uncertainty, reinforcement, expressive assessment, which are expressed by different linguistic means of various language levels (grammatical, lexical, etc.) not only in the languages of different systems, but even in one language. This is the specificity of the persuasion modality.

In the structure of the functionally semantic field of persuasion, the centre (core) stands out, in relation to which the other components represent the periphery. The centre of the field of persuasive modality should include the modal meanings stated above that express objective or 


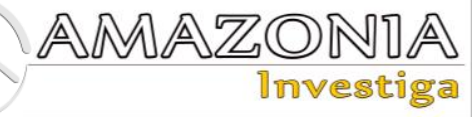

subjective modality. In the approach of this research the periphery includes, first, the meanings that lie on the "outer" boundary of modality, that is, the meanings that occupy an intermediate position between the actual modality and other linguistic phenomena; secondly, the meanings that cannot be reliably attributed to objective or subjective modality.

For the purpose of successful communication in open court, the speaker uses verbal and nonverbal means, concentrating on the communicative attitude.

Modality of persuasion as a universal conceptual category is characterized by the fact that the prosecutor selects the means of speech depending on his communicative intention.

The modality of persuasion can be expressed by syntactic, morphological, lexical and phonetic means.

It is known that in the languages under analysis (English and Ukrainian), one of the most important means of embodying modality is the morphological category of action, which is formed by a system of verb forms. Forms of mode of action are considered as a means of expressing objective modality, but the use of one form or another depends on the choice of the prosecutor.

Syntactic means of expressing the modality of persuasion in different types of sentences, phraseologised syntactic models, etc. are not used to depict reality of action but to express the modal-expressive attitude of the prosecutor (Shvetsova, 2012). It should be emphasized that modality, which is a product of communication and serves it, is manifested at the level of syntax as a syntactic function of morphological (structural), lexico-grammatical (modal words and particles) means, as well as special syntactic constructions that express modality grammatically, that is, without the participation of lexical (nominative) meanings of words.

The peculiarity of the prosecutor's speech is the use of various prosodic means to convey the modality of persuasion depending on the circumstances. Various prosody constructions can be used in different communicative situations, in communication with more or less familiar interlocutors and when performing various communicative functions. Exercising a familiar prosody elements people tend to have a casual conversation. In case a speech is formal, one of the interlocutors is higher in position than the other, and this peculiarity can be used when accusing someone. Besides, the main part of the prosecutor's speech can be delivered in a calm, restrained voice, while the final part can be characterized by a more excited prosody.

\section{Methodology}

The research is aimed at analysing and systematising the prosody peculiarities of persuasion in a prosecutor's speech in English and Ukrainian court. One of the tasks is to find some common characteristics in the two languages and the peculiar features, which distinguish the phonologically grounded characters in English and Ukrainian attitude of persuasion in prosecutor's speech.

The experimental material consists of English and Ukrainian speeches of the prosecutors (the total duration time is 16 hours).

The methods used in the research are: auditory analysis of the experimental material, contrastive analysis of the two languages under investigation, theoretical generalisation of the results.

Like any independent branch of linguistics, phonetics has its own methods of studying the sounding units. The oldest of them, but the one that has not lost its significance now, is called the method of direct observation. The specificity of this method is that the researcher, listening to the speech, draws conclusions about the general features and characteristics of individual sounds or groups of sounds, both in terms of articulation and acoustics.

Analysis and description of a language prosody from the standpoint of the phonetic approach should be based on the study of the material nature of prosodic characteristics of supersegmental units of a language (Korolova, 1989). It is known that the process of speech communication includes three phases: speech production (phonation, articulation), speech signal transmission in the form of sound waves propagated in an elastic medium according to physical laws (acoustic phase), and perception of speech signal by human auditory system (perception). Therefore, prosodic description of coherent speech can be carried out by characterizing the physiological processes of control of the elements of the speech tract, analysis of acoustic parameters of oscillating processes of the sound field propagating in the environment, or by studying the processes of acoustic signal perception by the ear to interpret 
properly the information transmitted by the speaker.

The most common approach is based on the description of prosody in terms of perceptual characteristics of a language; the differentiation of which in communication is provided by the melodic component, dynamic element, tempo of speech (including pauses), timber of voice, phrasal stress, rhythm. Almost each of these components correlates with the corresponding characteristics of the acoustic and phonation phase (Brovchenko \& Korolova, 2020) though it is impossible to speak of an unambiguous correspondence between them.

It should be noted that not all of these prosody components are studied in detail. Some of them (for example, melody and stress) are given a lot of attention in the scientific and educative literature in phonetics, while others (for example, timbre) are relatively poorly presented.

The approach to the study of prosody presented in this article assumes that the peculiarities of the prosodic system of persuasion in the prosecutor's conversation are considered in a rhetorical context that is the presented functional-semantic interpretation takes into account such categories as the aim of communication and its result. In this connection, the research of prosodic units' role in the implementation of the prosecutor's position in his speech (the sphere of auditor's personality presentation) and the adequate interpretation of the information by the listeners (the influence sphere, interaction of the prosecutor with the audience) is of a particular importance. Such an approach allows to see the influence of ethnos (social and cultural context) on the prosodic realization of speech, interaction dynamics of a sounding text and in addition to it to involve invariant characters of prosody together with the variable prosodic signs that are to demonstrate the reasons of prosody semantics variability.

The phonetic approach is based on the features of segmental and suprasegmental design of the utterance. In this study, the prosody features of persuasion modality presentation in prosecutors' speech of Ukraine and England are considered. The prosody of statements is recognized as an integral property of any communicative unit of the modal-semantic field of persuasion. Moreover, prosody, which involves a set of characteristics, is considered as one of the formal elements that constitute the national-linguistic identity of the phenomenon and depicts the specifics of a language on the whole.

\section{Results and Discussion}

Patterning prosody when researching the phonetic marks of persuasion in a prosecutor's speech

While examining the prosody of the prosecutor's juridical communication in English and Ukrainian, the main attention is paid to the semiotic aspect. It is known that prosody is used to express both linguistic and a wide range of para- and extralinguistic meanings.

The prosody of persuasion in the prosecutor's language is symbolic. It acts as a sign when it serves to indicate the completeness / incompleteness, certainty / uncertainty of the statement, as well as when it conveys the general emotional mood of the prosecutor.

It has been found that the functions of persuasion prosody in the language of the prosecutor's speech include the following: 1) organization and articulation of speech flow, 2) opposition of articulation units (general question / narrative in Ukrainian), 3) connection between the articulated units (pause), 4) expression of relations between elements of prosodic units (different degree of accentuation of selected phrase elements), 5) expression of modalemotional meanings, 6) actualization of pragmatic meanings (linguistic means that contribute to the success of a communicative act).

The prosody of persuasion should be considered one of the most important means of linguistic expressiveness, because on its basis it is possible to establish (restore) features of contextualsituational and pragmatically oriented use of statements, their relevance or irrelevance for these communication conditions, their subjective-modal meanings and accompanying connotations.

The supersegmental organization of the studied material was considered at the levels of phonetic word (rhythmic structure - RS), syntagms, phrases and text in general with the help of auditory analyses.

Investigating the problem of persuasion prosody in the prosecutor's statements, speech prosody has been defined as a combination of systemically conditioned prosodic features of communication, which includes the frequency of the fundamental tone, intensity and duration that correspond perceptually to the components of melody, loudness and tempo. 


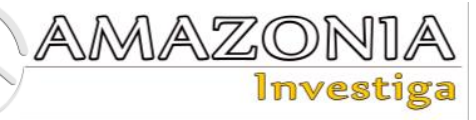

There is a good reason why many researchers consider the melodic component to be the most important prosodic structure. It is the melodic component of prosody that is easily perceived by the ear and has the maximum functional load. Therefore, the first system of signs that fixes pitch tones in a graphic form (tonograms) was developed for melody characteristics. Information about the dynamic component is reduced to the marks of stressed syllables (although a number of authors use notations that show the loudness of speech, but they are not common). The timbre components of prosody have no conventional notation for graphical representation of the corresponding prosodic characteristics. The image of the temporal components of intonation is still limited by indicating the duration of pauses as a rule.

It should be mentioned that with the help of existing notation systems the melodic features of communication can be partially reflected in tomograms, the reason is that only some acoustic characteristics of frequency changes can be presented in the proposed system of notation.

Still when expressing persuasion modality in the prosecutor's speech, the primary role belongs to the melody in both languages under investigation.

All elements of the syntagm (pre-scale, scale, nucleus and tail) differ in the design of the height component, and the most important in this case is the degree of functional and semantic interpretation of the nucleus, which is opposed to all other elements of the syntagm.

The type of nuclear tone, simple (descending, ascending, level) or complex (descendingascending, ascending-descending), is the basis of the prosodic characteristics of the syntagm (Brovchenko \& Korolova, 2020; Korolova, 1989; Dubrovskaya, 2010; Bickerton, 1996)

As to the post nuclear (tail) melody composition, it usually continues the movement of the fundamental tone in the nucleus, with no significant qualitative changes. It should be noted here that the appearance of a secondary emphasis on syllables of the tail can increase their semantic significance in the prosody construction of the phrase (especially in the Ukrainian language).

The type of the head plays a significant role in the transmission of communicative, modal and other semantic relations in communication process. There can be found ascending, descending and level heads according to the direction of movement of the fundamental tone within the syllables of the head, and monotonous, stepped, sliding and scandent ones depending on the form of melody in stressed and subsequently unstressed syllables within the syntagm.

The melodic design of the prehead is less involved in the reflecting the communicative orientation and semantic aspects of a phrase in comparison to the other segments of the syntagm, but compared to the unstressed syllables of the head, the prehead in most cases is more informative and more accurately pronounced by native speakers.

Let us consider in details the melodic characteristics of modal meanings within the functional-semantic field of persuasion in the speech of Ukrainian and English- prosecutors during court hearings.

According to the auditors' opinion the predominant nuclear tones in the prosecutor's statements were of a descending form in both languages under investigation. It should be mentioned that in English ascending and complex terminal tones were present. It can be explained by the fact that in English the semantics of the rising tones is broader than in Ukrainian. It shows the desire to involve the audience into communication, to make them feel a part of the action. The high frequency of the descending tones determined by auditors is not accidental. Kinetically falling tones perform the function of completeness, certainty, sound categorical.

Complex tones perform the function of underlining something and give the language a special emphasis and expressiveness. The high frequency of complex tones in the statements of the accuser in the process is not accidental, because his task is to draw the listener's attention to the subject of speech, to explain and highlight the most important points in the statements. This point of view coincides with the opinion of other researchers who examined the prosody of modality in public speeches. Thus, it has been stated that complex nuclear tones are most often used in public speech and conversational style (Brovchenko \& Korolova, 2020; Bybee 2003) The use of a complex configuration of melody (descending-ascending-descending) in the terminal position during the speech demonstrates the prosecutor's complete confidence in the reported fact, on the one hand, and that the meaning of what has been said improperly emphasized. 
According to the respondents' idea, in the prenuclear part of the statement the most informative is the prosody of the head. It is the direction of the tone in the head when presenting persuasion modality that affects the degree of persuasion modality expression. The predominance of level (in Ukrainian) head, the prevailing of descending and ascending scales in English was revealed. As to the change in the pitch of prosecutors' voice in stressed and unstressed syllables in the investigated languages, the following correlations are observed:

- $\quad$ use of The Low Level Head and The Middle Level Head to convey negative emotional values (e. g. roughness);

The Low Level Head reinforces the meaning of what is said and demonstrates the impact on the listener;

- $\quad$ use of The Low Descending Stepping Head, expresses "objections";

The Low Descending Stepping Head emphasizes the importance of the reported fact;

- presence of The Low Descending Sliding Head gives the prosecutor's statements tension and expresses such connotations as "reprimand", "remarks"; it is emphatic enough in communication;

- The Low Descending Scandent Head attaches importance to each emphasized word in the prosecutor's statements and convey such connotations as "outrage", "condemnation";

- presence of The Low Ascending Sliding Head manifests an increase in the degree of intensity of the expressed attitude.

- introduction of The Middle Ascending Sliding Head is used to emphasize the importance of each stressed word in the utterance.

The melodic design of the prosecutor's statements at the trial corresponds to the tasks set by the speaker. Statements that are characterized by a tonal contour consisting of a descending head and a low descending nuclear tone, express confidence of the speaker, sound categorical. A contour consisting of a low scandent head and a low descending nuclear tone conveys values such attitudes as indignation, disapproval, and so on.

The auditors' information evidences to a wide tonal range of statements related to the trial in the two languages. This fact suggests that the variability of the range of melodies reflects the difference in the degree of emotionality of the speaker and its subsequent expression in the utterances.

\section{Parameters of prosody examined in the research}

In a number of investigations, attempts have been made to correlate certain types of melodic design of individual segments of the syntagm with specific semiological units directly. However, most linguists believe that to distinguish the content of the melodic component of prosody cannot be realized by means of prosodic design of a syntagm segment, but to regard it as a result of the interaction of prehead, head and nucleus that are functionally related in the speech act.

The interaction nature of melody height and the level of pressure in sounding speech is of particular importance in the interpretation of prosodic data analysis at the perceptual level. The dynamic component of prosody, which is interpreted at the perceptual level as the loudness of speech, has its correlate at the articulatory level, i. e. the degree of air flow pressure on the vocal cords (enforcement leads to an increase in the amplitude of their oscillations). The magnitude of air pressure is determined by a number of factors and, above all, factors of a purely physiological order: different muscular efforts of the speaker and various degrees of the respiratory muscles tension in the process of phonation. Note that loudness (perceptual parameter) of the prosecutor's voice depends not only on the amplitude of oscillations of the vocal cords, but also on the frequency of these oscillations. Therefore, separate consideration of melody and loudness is of a conditional character.

The most significant evidence from the point of view of the prosecution was expediently highlighted in a loud voice, even if the prosecutor's speech lasted not more than a minute (and especially in case, when the audience is already a little tired).

The dynamic component of speech signal was considered on the one hand as an independent parameter of prosodic language design, on the other - as an integral part of verbal and syntagmatic stress, a rhythm-creating factor was taken into account as well. It is necessary to pay attention to the nature of changes that take place within the dynamic parameter in a verbal and contextual respect in the prosecutor's speech. One of the important distinctive characters in the 


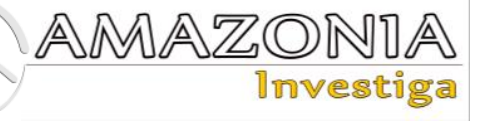

experimental data is that the maximum intensity in an isolated word was localized in both stressed and unstressed syllables, while in contextual proclamation the localization of intensity maximum was almost always in the stressed syllable The value of the intensity difference between the initial and final vowel in the word is one of substantial indices in the analysis of the dynamic component. It should be stated that the dynamic component is significantly higher when pronouncing a word in a continuous speech of the prosecutor than in an isolated form.

It is necessary to consider the question of the direct influence of voice loudness on the prosodic design of the syntagm (participation of loudness in phrase stress and rhythmic structure of utterances is not taken into consideration).

Loudness changes primarily signal about contrasting the most important fragments of speech to the remarks and explanations that go beyond the main topic of the message. An important role of the dynamic component of the prosecutor's speech prosody is in embodying various emotional and modal connotations of the language. Here the dynamic component of prosody can vary from a very quiet one (when expressing a desire to calm the interlocutor) to a very loud one (when expressing a violent objection, indignation).

It should be borne in mind that the deviation of loudness from the average level was sometimes caused by reasons that are not related to the semantic aspect of the language. For example, the prosecutor's voice sounded louder (besides the cases when the modality of persuasion was expressed) when there was noise in the courtroom or the communicants were at a considerable distance from each other.

Too loud speech quickly tires the audience and can even irritate. Therefore, in order to increase the efficiency of speech perception, the prosecutor announced his message at a medium loudness. At the same time, he remembered that the variation of speech loudness had a positive effect, which allowed to avoid monotony and reduce listeners' fatigue.

One of the means of prosodic exploitation of various aspects of the semantic plan, including the attitude of the speaker to the content of the speech, to the situation of the conversation is the tempo of speech. It should be mentioned that the choice of tempo affects the quality of perception of the information the speaker shares. The following factors influence the tempo: syntagm length (the longer is the segment the more syllables are pronounced at a unit of time), loudness (the quieter the speech is the slower it is produces), language style (official and oratorical styles differ in the slow pace of realization, nonofficial is accelerated) (Dubovsky \& Yermolenko, 1987).

An important prosodic characteristic is the temporal correlation of speech segments. The main parameters that characterize this aspect of prosody are the duration of the speech segments and the rate the individual segments are produced. At all three levels of speech actualization (speech production, acoustic level and perception) the temporal component of prosody is physically homogeneous. However, in auditory perception, the element of subjectivity prevails in the quantitative assessment of this parameter.

Tempo occupies one of the most important places in the prosecutor's speech during the trial. The tempo of the prosecutor's speech varies depending on the content of the statement, on the individual characteristics of the speaker and his emotional state. During the experimental study, the prosecutor's speech most often takes place in a situation of emotional tension, which is manifested in the accelerated pace of the report. However, the excessive speed did not allow to perceive all the information provided, and too slow speech, in its turn, gave the impression to the participants of the process that the public prosecutor's language was uncertain due to the lack of information about the case or lack of evidence.

It was noticed that when pronounced at a constant pace (120 words per minute) the prosecutor's speech was difficult to perceive, the reason lies in the fact that it is tiresome to perceive and interpret adequately the information on different topics (statement of circumstances, characteristics of the defendant and assessment of actions) coming at the same pace. Analysing the case file, the prosecutor reflects on the truth or falsity of some evidence, argues, refutes, draws conclusions. In addition, in almost every speech there are the so-called common places where the prosecutor raises and considers moral issues. Naturally, all these structural parts cannot be pronounced at the same pace. The most important of them were spoken at a slow tempo, since they emphasized the importance of prosecutor's reflection, their significance; slowing the tempo down makes the listeners pay attention to the opinion expressed. Unimportant parts of speech were pronounced a little faster; 
emotional assessment of any phenomena was also realized at an accelerated pace. The known information was reported in the prosecutor's speech faster than new. Facts of particular importance were produced more slowly than non-essential parts of the statement.

The rate of speech is closely related to such phonetic phenomena as reduction, assimilation of sounds in the flow of speech. At the same time, the faster is the tempo of the prosecutor's speech, the more abbreviated and assimilated sounds there are.

\section{Semantics of prosody parameters variation in prosecutor's persuasive speech}

According to the auditors' statement the tempo of prosecutor's speech was unstable. The results of the auditory analysis showed that the informants determined an accelerated tempo in some affirmative and interrogative sentences. The acceleration demonstrated nervousness, desire to change the topic. The prosecutor's speech was perceived as a more convincing one when spoken confidently, slowly; this manner emphasized the objectivity of the conclusions and strengthened the modality of persuasion.

In the Ukrainian language, the nature of the temporal component functioning in the prosecutor's speech is basically similar to the one in English. Some differences are due to the fact that in English (in contrary to Ukrainian) duration is a relevant phonetic feature not only at the supersegmental but also at the segmental level. In general, the tempo of the prosecutor's speech in English is much faster than the tempo of the Ukrainian language.

Pause is a true ally of the prosecutor's persuasive speech during the court debates. The tempo of speech is directly related to the concept of pause. The pause could be either a real phenomenon or existed only in the imagination of the listeners. The first type of pauses was characterized by complete stop in phonation. The second type of pauses (imaginary) was due to a number of different reasons, namely: some changes in the height of melody contour, certain changes in tempo, elision of neighbouring stressed syllables and other phenomena. All of the above mentioned phenomena in the prosodic model of persuasion were perceived by the ear as pauses between the intonation groups, although physically there was no stop in the process of speech production. By means of a pause, the prosecutor highlights the key idea of his speech, asks questions to clarify something or hint at some acts.

In the research there were three types of pauses identified in the speech of the prosecutor.

- A semantic pause that was regularly used in prosecutor's speech at the end of a sentence, a sense-group or a paragraph (throughout speech). This type of pause, in its turn, allowed the listeners to understand the prosecutor's opinion and get ready to perceive the new information. Here is the example of an introduction of Prosecutor's speech in court.

Під час досудового розслідування встановлено, щзо обвинувачена Волинська Анна Георгївна, 20.09.2012 року близько 21 години, під час сімейної святкової вечері в ї̈ квартирі в місті Києві, приревнувала Задоєва Миколу Сергійовича, з яким вона збиралась одружуватись, до дочки, Волинської Марії Володимирівни, внаслідок чого виникла сварка. II Під час з'ясування стосунків обвинувачена, що перебувала у стані алкогольного сп'яніння, розлютилася, схопила зі столу пляшку шампанського $i$ з силою вдарила потерпілого по голові. || Згідно 3 висновку судово-медичної експертизи, смерть Задоєва настала миттєво від проникаючого поранення черепа 3 ушкодженням мозку. "| Таким чином, умисні дї Волинської, щзо виразились у вбивстві, були кваліфіковані обвинуваченням за частиною першою, статті 115 Кримінального Кодексу. II

(- During the pre-trial investigation| it was established | that the accused Anna G. Volynska,| on September 20, 2012 at about 9 pm, | during holiday dinner of the family in her apartment in Kyiv, |got jealous of Mykola S. Zadoev, | whom she was going to marry to her daughter|Maria Volodymyrivna, | resulted in a quarrel. || While clarifying the relations | the accused,| who was in a state of intoxication, | became angry,| grabbed a bottle of champagne from the table | and hit the victim on the head with force. II According to the forensic medical examination,| Zadoev's death occurred instantly from a penetrating skull injury with brain damage. II Thus, | Volynska's intentional actions $\mid$ that found place in the murder,| were qualified by the accusation as part one, Article 115 of the Criminal Code. II)

- I just wanted to tell you | the first thing | that struck me in your statement this morning | was that you're terrified $\|$ and I just wanted to let you know | I'm very sorry. || That's not right || I know 


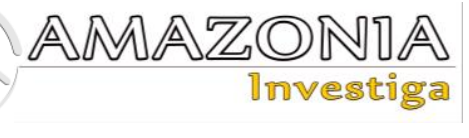

this is stressful and so I would like to set for some guidelines | that maybe will alleviate that a little bit. II If I ask you a question| that you don't understand $\mid$ please ask me to clarify it $\mid$ or ask it in a different way. II When I ask questions | sometimes I'll refer back to other information you've provided $\mid$ if I do that $\mid$ and I get it wrong | please correct me. ||

- A dramatic pause was used by the prosecutor to penetrate into the listeners' subconscious and give the audience time to assess the significance of the words he said. For example:

- Яросименко, от Ви втікли, | ну, а допомогу викликати? || Ну, принаймні міліцію. || (Yarosimenko, you ran away, I well, what about calling for help? || Well, at least ... the police. (|) - Thank you Mr chairman when we were stopped you were going to tell us a third correction | that you wanted to make on that statement I oh I'm sorry | the letter to the senator Feinstein.||

- An emphatic pause was used to emphasize specific key points that were important in convincing the litigants.

- Ось, дивіться: оией індійський томагавк мирно висів у вбитого на стіні | весь час, | а потім четвертого липня цей томагавк знайшли на тілі, І а точніше в голові загиблого. II

(- Here, look: this Indian tomahawk hung peacefully at the victim on the wall $\mid$ all the time, I and then on the fourth of July this tomahawk was found on the body, I or rather in the head of the deceased. II)

- I'm not going to ask you to guess $\mid$ I know it was a long time ago I If you do estimate | please let me know | that you're estimating. Okay?||

The use of a pause in the prosecutor's speech allows to place semantic accents, as well as to add a little intrigue, to enhance the emotional impact on the opponent. Example:

Саме иікаво, І щзо на изьому знарядді зброї вбивства були знайдені відбитки ваших пальців. || Ви можете прокоментувати цее чи ні? \| A? ॥ Як ви туди потрапили? || (- The most interesting thing is that your fingerprints were found on this murder weapon. II Can you comment on this or not? || A? || How did you get there? II)

- Everybody responded to the sound of their name | except Jordan Davis: || he was lying in the backseat with his head | and Leland Brunson's ...
There were no initial pauses at the beginning of speech in the prosecutor's speech. This is due to the fact that this type of a pause is evaluative (for example, to consider the appearance, clothing of the speaker), which is not typical of the prosecutor, since by the stage of the debate he had not only considered but a definite opinion on his behaviour in court, on the issues raised by him has already been formed. That is why the prosecutor is ready begins his speech immediately.

The data of the experimental-phonetic study showed that the actual duration of pauses of either of the three types is not strictly fixed and depends on many extralinguistic factors. In fact, we are not talking about the characteristics of the absolute duration of pauses, but about their relative extension in time.

A strong, flexible, expressive voice accurately conveys the attitude of the prosecutor to the subject of conversation, conveys all the semantic and emotional nuances of speech. The prosecutorls voice sounds loudly enough to be heard by all the participants in the trial. By force of voice, the prosecutor convinces each member of the court by his thoughts or feelings. To do this, the voice changes in pitch and has a wide range of melody, loudness/ tempo and a variety of timbre connotations. Smooth transitions from one key point to another add expressiveness to his speech, convey the thoughts in completeness and variety of shades. During the interrogation, there were cases when the poverty of the vocal range of the prosecutor's speech led to monotony, which prevented him from getting to the heart of the matter, blunted the perception of speech. This happened when the prosecutor knew little about the case file, did not think through the evidence. Right after the interruptions of voice happened in the speech continuum he became deaf, intermittent, suffocated. The quality of language perception under the above mentioned conditions decreased. The prosecutor, with a thin, weak, uncertain voice, could not evoke respect of the audience, did not make them believe what they were to be convinced in.

At the same time, it is necessary to remember that timbre in the course of conveying emotional and modal meanings of the prosecutor's speech acts in close interaction with other components of intonation. For example, when pronouncing utterances that have negative emotional and modal connotations, alongside with the use of the appropriate timbre characteristics in communication, there is a selection of the keyword in the phrase by lengthening the pause, 
one can hear that the key word is marked with the help of a pause, increase of the melodic component variability rate on the stressed vowel, longer pronunciation of stressed syllables (compared to the production of emotionally neutral phrases). Thus, emotional-modal attitudes of persuasion are represented in sounding communication by acoustic features of different nature, which allows a person to interpret them on a perceptual level adequately.

The timbre characteristics of speech allow the listeners to judge the psychophysiological state of the speaker, his attitude to the object of speech and the situation, i.e. to interpret the specific modal-emotional meaning conveyed in the utterance correctly. The main acoustic correlates of the timbre characteristics of the speech signal are the indicators of high-frequency areas of sound energy. Being one of the obligatory elements of speech prosody design, the timbre acts in close interaction with the other components of prosody.

An important component of the speech prosody is the sentence stress, which, depending on the studied unit, may turn out to be in a syntagm, phrase and larger units of speech, such as the phrase complex, the text. A distinctive feature of this component of prosody, in comparison with the previously considered ones, is its complex nature, because at the acoustic level it is realized as a result of the interaction of the basic physical parameters of the phonetic structure: frequency, dynamics and tempo.

The role of different types of sentence stress (normative, logical, emphatic) in the oral speech construction is difficult to overestimate. The interaction and interdependence of all these types of stress in the phrase in order to highlight prosaically the semantic centre of a phrase, are caused by the communicative tasks of speech, morphological and syntactic features of language, lexical structure of the communication segment and its stylistic features.

The logical type of sentence stress, emphatic, syntagmatic accents contribute to the differentiation of various degrees of emphasis, contrast and give the modal persuasive meaning a manipulative shade. With the help of sentence emphasis, prosecutors try to express their ideas, show confidence and encourage the addressee to react to the information heard. As a component of the speech portrait of the English and Ukrainian-speaking prosecutor, the phrasal emphasis in the convincing statements of the prosecutors highlights the most important words semantically, emphasizing at the same time their professional characteristics. Example:

- The 'third / shot, I the' fatal \shot, entered 'entered the victim's' back as he' lay 'helpless on the \sidewalk, face' face \down.

Analysing the features of sentence stress as a way to emphasize the semantic centre of the syntagm, it was found that the speech of prosecutors is dominated by the logical type of emphasis (force type), which, in its turn, indicates the prosecutor's attitude to the addressee and conveys his emotional state. Marking the word with a logical stress in the speeches of prosecutors is often crucial not only for interpreting the logical and semantic structure of a convincing statement, that underlines the relationship between its members, but also for the purpose of determining the modal orientation of the phrase. Example:

- „Отже, І в діях 'Мироненка 'наявний 'склад ззлочину | 'передбачений 4.3 cm.136 „ККУ, । тому „прОшу | суд | притяг нути | 'підсудного до 'кримінальної 'відповідальності у 'вигляді 'позбавлення 'волі строком | на 3, рОки. || (So, I in the 'actions of 'Myronenko there's 'existing 'the ,crime I 'provided by 'Part 3 of 'Article 136 of the CCU, | therefore I re quEst | the 'court $\mid$ to call $\mid$ 'the de'fendant to 'criminal 'responsibility by 'imprisonment in the 'term $\mid$ of 3. yEArs. I)

As can be seen from the example given above, the most important word in the semantic plan is marked in the Ukrainian prosecutor's speech with a logical emphasis in order to attract attention of the court and increase the pragmatic effect of his efforts to convince the addressee.

When studying the peculiarities of the melody variations in the prosecutors' speeches in the two languages under investigation, it should be remembered that this component is closely related to phrasal stress: pitch, melodic range in a sentence changes in distinctive points, it is marked by the amplified loudness and accents, the interval changes as well. In case the phrasal stress is changed, the melodic pattern of the sentence will also change.

It should not be forgotten that the change in the voice's force, undoubtedly has a positive effect on the impression of the speech on the whole. The most important moments are marked by the voice and it does not allow the listener to get tired, even during a long speech. In this regard, the loudness of speech itself, regardless of the 


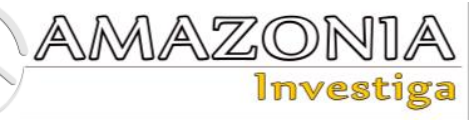

connection with the accent, can participate in expressing certain modal meanings.

The analysed types of phrasal stress in prosecutors' speech in English and Ukrainian allow us to state the importance of the presence of a dynamic component in a sentence stress.

Thus, it can be concluded that the persuasive speech of the prosecutor during the trial depends on the communicative situation (Levy, 1979), which under the circumstances is an extralinguistic factor that distinguishes the prosecutor's speech in court as a special sublanguage and from the point of view of illocutive acts classification it should be treated as a speech act belonging to a court's language.

In the study of different communicative types of statements used by the prosecutor, it was found that the perlocutive effect of persuasion is best demonstrated in the affirmative and interrogative statements. In the prosecutor's affirmative statements in court, the selection of the prosodic centre is accented by means of changing the pitch, volume, tempo characters. The phrasal stress in the prosecutor's interrogative statements in court is emphatic, and the emphasis is greatly created by the tonal component in English though the dynamic means take part in marking the emphatic centre. In the Ukrainian language, the phrasal stress in interrogative utterances is usually characterized by an increase of pitch on the vowel of the last stressed word in a syntagm, i.e. on its semantic centre.

Directions in court have a less perlocutive effect of persuasion in the prosecutor's phrases in the two languages, and the affirmative and interrogative statements are the ones involved in achieving the effect of persuasion.

Giving evidence, as a rule, the prosecutor did not read his speech but spoke distinctly and loudly, so that everyone could hear well. The following should be noted: changes in pitch, volume, tempo and duration of pauses helped to avoid the monotony of the prosecutor's speech, made it brighter and more convincing for the audience, which undoubtedly had a positive effect on the effect of his speech on the audience.

Rhythm, as well as phrasal stress, is a complex component of speech prosody, the result of the interaction of basic physical parameters of the phonetic structure: fundamental frequency, dynamics and tempo. Regular repetition of stressed and unstressed syllables in time (their synchronism) determines the rhythmicality of speech. It is clear that emphasis is of primary importance in the rhythmic organization of speech. When considering issues related to speech rhythm, it is necessary to remember the multilevel nature of this component of prosody (rhythm of a syllable, rhythm of speech, rhythm of a syntagm), its ability to implement simultaneously in all the above mentioned forms. In conclusion to the inventory-taxonomic review of prosodic means of speech, it can be stated that there are distinct markers of the significant difference in the degree of informativity in melody, loudness, tempo, timbre, rhythm and phrasal stress in terms of logical-semantic and emotional-modal meanings; the complex nature of these prosodic components in speech are to be taken into account. Therefore, an important problem is not only the study of the role of each of these components in the implementation of prosody various linguistic functions, but also the establishment of their hierarchy, relationship and interdependence in the phonetic system of a language.

The most characteristic transformations of a prosodic contour occur when the modal function of persuasion interacts with the function of accent location.

\section{Interaction mechanism of prosody parameters in a persuasive prosecutor's speech}

Regarding the mechanism of prosody interaction when exercising two functions simultaneously: the modal function of persuasion and the function of sentence stress marking; it should be noted that in many cases the accent in a sentence provides only the logical connection between the words, and the modal labelling of these relations is minimal or absent:

- У минулому рочі Ви надіслали \иста. (Last year you sent $\backslash$ a letter).

- They were each arrested and charged with \ theft in the first degree.

Under these conditions, the function of actual articulation is not included into the scope of the environment in relation to the modal function of prosody and these two functions are realized autonomously.

If the selected element of the syntagm has a modal semantics or has a modal connotation alongside with the expression of intellectual and logical meanings, then these two functions of intonation are manifested in combination with each other. Most often special markers are not used to demonstrate the actual division, and the 
same prosody markers that transfer modal relations are applied. It should be noted that, as a rule, not only prosodic differentiators of certain modal relations are used here, but the markers that amplify these meanings. This is the way, the $t$ subjective modality meanings (attitudes) of persuasion can be conveyed. So, in the examples:

\section{(1) ДВА роки (2) два РОКИ [(1) ТWО years (2) two YEARS]}

(1) ONE year (2) one YEAR

The location of the phrasal emphasis on the word "year" in the first sentence gives the message the attitude of prolonging the duration of the event.

This dominance of the modal function is most characteristic of the interaction of the accent location function with the function of emotionalevaluative meaning. Most often, the prosody of persuasion performs a third function, emotional in the broadest sense of the term, reflecting the emotional state, the mood of the speaker, and not just his attitude to what is being said.

As an extreme manifestation of this situation of joint action of the two functions, the logical aspect can be completely lost when marking the rhematic part, and the content of the rheme is in the modal meaning that is reflected in it, for example:

- Який БУВ день! Хто міг би подумати, щзо так станеться! (What a day! Who would have thought that would happen!)

- How good it WAS for you!

Here we must talk about the complete equivalence of these two functions of prosody. This is expressed by the fact that the prosody performing the two functions together, coincides completely with the one used for the isolated phrase of either, which are a part of this complex of emotional and modal meaning: different components of the timber, complex tones (ascending-descending), tempo slowing down (increased duration of the stressed vowel), etc.

The systematization of mechanisms of interaction of the modal function of prosody with the function of accent localization described in this section completely correlates with the classification of phrasal stress types accepted in the scientific literature. The first of the situations considered here (autonomous manifestation of functions) corresponds to the case of logical emphasis, the second and third (complex manifestation) - emphatic emphasis in the syntagm (Brovchenko \& Korolova, 2020).
The mechanism of interaction of the function of semantic relations between the elements of the syntagms and the modal function of prosody is typologically similar in the compared languages.

The differences between English and Ukrainian in this aspect are primarily due to the fact that within each language system the grammatical structure and lexical structure determine the phrasal accentuation to some extent. The discrepancy between these norms in the compared languages at the level of word stress is seen in the initial position of the stressed syllable in an English word and in greater mobility of the stressed syllable position in a Ukrainian word.

In general, English and Ukrainian prosecutors use accentuation to convey subtle nuances of the meanings of persuasion modality, making the listener to react in some way to the perceived information.

The results obtained during the experimental analysis confirmed the hypothesis that the prosodic organization of a judicial utterance is closely related to the function of emotional pragmatics character of the communication process, namely, persuasion. Prosodic means are decisive to convey personal prosecutor's convenience in one or another party's innocence in the trial.

Prosody of persuasion in the language of the prosecutor is the most important means of personalization, because only in sounding speech the expressiveness acquires its true meaning, realizing all the variety of social and individual shades of persuasion semantics and connotations. Based on the fact that in a broad sense, the entire prosody repertoire of the prosecutor can be considered as a means of personalization, we divided the prosodic means of personalization into socio-status and individual. The results of the research have shown that the social status of the speakers in terms of socio-economic, sociometric and role playing factors is approximately the same in two cultures, which is manifested in the implementation of stereotypical rules of phonetic behaviour of the speakers. Rhetorically significant are those prosodic means that convey the individual and personal qualities of the prosecutor and are part of his individual style.

Identification is carried out by means of addressing and dialogue. In the research the addressing means and the dialogue factors used in the prosecutor's speech (appeals to knowledge and experience of the audience, involvement of 


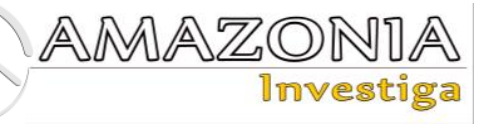

the audience in a joint mental process, questionand-answer procedure, rhetorical questions, direct questions to the audience) are defined and systematized. Dictatems, which realize direct interaction of the speaker and the audience, are the carriers of the conversational style, prosody takes an active part to form the last.

The specificity of rhetorical discourse that is aimed at pragmatic influence the stereotypical and creative aspects, determines the need to include the category of expressiveness/ which combines the influential power of an utterance and its creative nature. The prosecutor's speech is dominated by intellectual expressiveness (argumentation and harmony of presentation). The expressiveness of the persuasive speech of the prosecutor is also ensured by such rhetorical figures as repetitions:

- До иъього часу, пане Іванов, Ви буди згодні на покарання, згодні на визнання свойх помилок, згодні з усіма твердженнями. Що ж тепер сталося? (- Until then, Mr. Ivanov, you will agree to the punishment, agree to admit your mistakes, agree with all the allegations. What happened now?)

- Really, was that cool or what? It was cool indeed...

The role of prosody in formation of the speech expressiveness is not limited to its participation in the rhetorical figures implementation. Prosody acts as an independent means of expression. The expressiveness of the prosecutor's speech is formed by two opposite tendencies that characterize its prosodic design - recurrence (e.g., prosody patterns repetitions) and contrast (contrasting prosodic design of segments of the text when changing the tone, text components that carry rational and emotionally influential information). The most important means of expression is an emphatic (rhetorical) pause, which marks the most significant parts of the text:

- Хто ж був ініціатором злочину?....||..Ви стверджуєте, що Семенюк, він - що Ви! (Who was the initiator of the crime? .... $\|$ (... You claim that Semeniuk, he - that you!)

- Both prosecution witnesses also testified under oath that Mr Dreamer gave the Toyota to Ms Simpson as a present. The ownership issue is merely an excuse dreamed up by the accused to explain why he kept Ms Simpson under close surveillance ... || ... You should find the accused guilty as charged ... || ... May it please the court. Summarizing this part of the study, it should be noted that all components of persuasive speech of the prosecutor are influenced by two trends: the first involves the units of the language to implement persuasion within the prototype model of rhetorical discourse of a particular genre; the second depicts the speaker's desire for optimal self-expression in the process of interaction with the listeners. As a result, stereotypical and creative aspects of speech are formed.

Thus, it can be stated that in both languages (English and Ukrainian) an utterance becomes emphatic due to the following prosodic means of persuasion in a prosecutor's speech:

1. Changes of tempo.

2. Changes of the pitch of a voice.

3. Replacements of the rising tone with the falling one and vice versa.

4. Usage of complex tones.

5. Use of an interrupted ascending or descending scale.

6. Change of sentence stress type.

7. Division of a sense group into two or more parts.

The results of phonetic research testify that the modal meanings of persuasion in the speech of a prosecutor are stable and monosemantic; they are typologically similar in both compared languages. The role of the dynamic component of prosody among the other relevant characteristics is predominant; it is true for all components of the semantic field of persuasion.

Language specificity is manifested with some difference between the exploited prosody markers. Thus, in the Ukrainian language the prehead is characterized by a lower pitch level than the pre-head in English. When strong emotions are expressed in the English language, the fundamental frequency interval in the nucleus and a frequency range of an utterance are more contrastive in comparison to the Ukrainian language. In English, the maximal intensity parameters, together with the maximal parameters of fundamental frequency, gravitate to the first stressed syllable; in the Ukrainian language to the main stressed syllable.

There is some difference in a rising tone while expressing incompleteness (regarded as the factor that defines semantic dependence between the sense groups): in the Ukrainian language the level of the final part of the nuclear kinetic tone is higher than in the first stressed syllable, while in the English language the level of the ascending nuclear tone does not reach the level of the first stressed syllable in the sense group. 


\section{Conclusions}

The important task of the comparative study of prosodic means conveying the modal information in speech in the English and Ukrainian languages is to define the similar and distinctive features in the sphere of formal (inventory-taxonomic) aspect of prosody and its semantics. The zone of typological similarity of intonational means that correlate with the attitudinal semantics is prevailing. Both, (some separate elements) which correlate with the prosody contour and their complexes (i.e. the prosodic structures which express the sense) are characterized by common features.

While describing the first of these aspects of typological similarity of prosody in the compared languages, it should be remarked that the parameters of the pitch component of intonation are most informative when differentiating attitudinal meanings: the type of nuclear tone and character of melody modification in the other segments of the sense group; the level of fundamental frequency; the interval and the rate of melody component alteration. Usually, a falling tone conveys meanings of definiteness, completeness, and maturity, unlike a rising tone that expresses the opposite attitudinal meanings those of uncertainty, incompleteness, and imperfection. However, the initial level of the kinetic tone and its alteration interval influence the perception and semantic interpretation of the nuclear tone most essentially.

Finally, the typological generality of the Ukrainian and the English languages is brightly demonstrated by the similar mechanisms of prosodic means interaction in the process of conveying the attitudinal meanings by nonprosodic means that express modality. The intralinguistic specificity of these aspects is connected with the peculiarities of the grammatical and lexical structure of the compared languages and the difference in the significance of the acoustic parameters when executing various functions of prosody. The specificity of interaction between prosodic and grammar means when expressing persuasion in Ukrainian and English prosecutor's speech is caused by a degree of distinction between the grammatical and vocabulary systems of the compared languages (synthetically in Ukrainian and analytical in English). This, in turn, instigates an occurrence of particular lingual features in the accent-rhythmic structure of a sense group. Alongside a significant number of the form words that are not stressed in the English language (unlike Ukrainian), the tendency to pronounce semi-notional words (personal and possessive pronouns and modal verbs) as unstressed ones is wide spread.

The prosody in the function presenting the communicative type of an utterance practically tightly interacts with the function conveying the modal meaning. The attitudinal connotation that is at the fundamentals of a specific communicative type defines the choice of prosody used in this communicative type.

In spite of the availability of a number of specific language peculiarities in the persuasive prosody the character of the correlation mechanism "prosody-meaning" is completely identical in the compared languages. More than that, the most essential features of these mechanisms could be treated as language universals.

The above mentioned determines the isomorphism of prosody mechanisms mutual development.

\section{Bibliographic references}

Aristotle (1978). Rhetoric. Ancient rhetoric. Moscow: Labirint.

Baum, L. (2006). Judges and Their Audiences: A Perspective on Judicial Behavior. New Jersey: Princeton University Press.

Biber, D. (1988). Variation across Speech and Writing. New York: Cambridge University Press.

Bickerton, D. (1996). Language and Human Behaviour. Washington: University of Washington Press.

Brovchenko, T. O. \& Korolova, T. M. (2020). Phonetics of the English language (contrastive analysis of English and Ukrainian pronunciation). Odesa: Helvetyka.

Bybee, J. L. (2003). Phonology and Language Use. Cambridge: Cambridge University Press.

Chemerinsky, E. (2016). Federal Jurisdiction (Aspen Student Treatise) (Aspen Treatise) [the $7^{\text {th }}$ ed.]. Alphen aan den Rijn: Wolters Kluwer. ISBN-13: 978-1454876618. ISBN10: 1454876611

Dowis, R. (1999). The lost art of the great speech: how to write it, how to deliver it. AMACOM Div American Mgmt Assn.

Dubovsky, Y., \& Yermolenko, G. (1987). Attitudinal semantics of prosody and its metalanguage. Proc. XI-th ICPhS Vol. 5. Tallin.

Dubrovskaya, T.V. (2010). Judicial discourse: speech behavior of a judge. (Dissertation for the degree of candidate of philological 


\section{AMA}

sciences). Saratov: Institute of Philology and Journalism of the State Educational Institution of Higher Professional Education "Saratov State University named after N. G. Chernyshevsky".

Gold, V. (1987). Psychological Manipulation in the Courtroom. Neb. L. Rev, 66. Recovered from

ps://digitalcommons.unl.edu/nlr/vol66/iss3/1

Jespersen, O. (1958). Philosophy of grammar. Moscow: Inostrannaya literature.

Klimovich, O.V. (2016). Language Identity of Attorney in the Context of Juridic Discourse (based on the speeches of S. A. Andrievsky and N. P. Karabchevsky). (Dissertation for the degree of candidate of philological sciences). The Russian Language. Ufa: Federal State Budgetary Educational Institution of Higher Education "Bashkir State University". Recovered from https://bashedu.ru/sites/default/files/dissovet s_files/disrab/dissertaciya_klimovich_o.v..p df

Korolova, T. M. (1989). The mechanism of interaction of linguistic means when transferring modal attitudes. Linguistics, 2.

Laufer, N. I. (1993). Confident and convinced: two types of epistemic states. Logical analysis of language. Mental actions, 6 .

Levy, D. M. (1979). Communicative goals and strategies: Between discourse and syntax. Syntax and Semantics. Vol. 12. New York: Discourse and Syntax

Meshchaninov, I. I. (1946). Conceptual categories and grammatical concepts. 1 . Moscow: Moscow State University Bulletin.

Palmer, F. R. (1974). Modality and the English verbals. London, New York: Longman linguistics library.

Panasenko, N. (2016). Functional-semantic types of speech in journalistic messages. Megatrends and media: Critique in media, critique of media: Conference proceedings from international scientific conference on the 19th - 20th April, 2016, Congress Hall of the Slovak Academy of Science Smolenice, Slovak Republic.

Panasenko, N., Greguš, L. \& Zabuzhanska, I. (2018). Conflict, confrontation, and war reflected in mass media: Semantic wars, their victors and victims. Lege artis. Language yesterday, today, tomorrow. The journal of University of SS Cyril and Methodius in Trnava. Warsaw: De Gruyter Poland, III (2), p. 132-163. DOI: 10.2478/lart-2018-0017

Peshkovsky, A. M. (1956). Russian syntax in scientific coverage. Moscow: Uchpedgiz.

Schwartz, B. (1997). A Book of Legal Lists: The Best and Worst in American Law, with 150 Court and Judge Trivia Questions. New York: Oxford University Press.

Shevchenko N. V. (1983). Oral official speech in different situations (based on the speech of lawyers). (Synopsis for the thesis for the candidate degree in philological sciences). Russian language. Saratov [in Russian].

Shulga, K. S. (2016). The role of the prosecutor in the debate of the parties. Young scientist. 10. Kazan.

Shvedov, M. (ed.). (1980). Russian Grammar. Volume 1-2. Moscow: Nauka.

Shvetsova, V. (2012). Features of the structure of the prosecutor's speech in judicial discourse. The Latest Philology, 44. Mykolayiv: Petro Mohyla University.

Spence, G. (1996). How to Argue \& Win Every Time: At Home, At Work, In Court, Everywhere, Everyday. New York: St. Martin's Griffin.

Tiersma, P. M. (1999). Legal Language. Chicago: The University of Chicago Press.

Vargas, D. (1984). Two types of legal discourse: Transitivity in American appellate opinion and casebooks. Studies of legal discourse. Danet - Amsterdam.

Vinogradov, V. V. (1975). Selected Works. Studies in Russian grammar. Moscow: Nauka.

Vorobey, P., Felyk, V., Niebytov, A., Matviichuk, V., \& Vorobey, O. (2021). Nature and significance of the State's criminal law policy. Amazonia Investiga, 10(39), 225-231. Recovered from https://doi.org/10.34069/AI/2021.39.03.22

Vinogradov, V. V. (1986). The Russian language. Grammar teaching about the word [3rd ed.]. Moscow: Vysshaia shkola.

Wang, J. A. (2004). Study on the Verbal Interaction in Adversarial Courtroom Trial. Applied Linguistics, 3. 